\title{
Must plagiarism thrive?
}

\author{
BY A SPECIAL CORRESPONDENT
}

Last year, according to Index Medicus, Dr E A K Alsabti published 13 scientific articles, but at least five of these were plagiarised. Attention was first drawn to this in April of this year when Professor Wheelock of Jefferson Medical College in Philadelphia wrote to the Lancet ${ }^{1}$ He pointed out that two-thirds of a review article published under Alsabti's name in two European journals (fournal of Cancer Research and Oncology, ${ }^{2}$ and Neoplasma $a^{3}$ ) was an "almost verbatim copy" of part of one of his grant applications. The rest of the article also came from work of Professor Wheelock. Dr Alsabti had worked in Professor Wheelock's laboratory and so had had access to the documents but had not contributed to them.

\section{Pettingale and Tee}

There appear to be differences in the serum protein levels between women with breast cancer and those with benign breast disease. These differences are seen preoperatively at the earliest time of clinical detection of a breast tumour and do not appear to be related to the age difference between the groups.

Raised serum caeruloplasmin has been reported previously in patients with both cancer and chronic inflammatory disease (Sternlieb and Scheinberg, 1961; Snyder and Ashwell, 1971), but an increase in $\beta_{2}$ glycoprotein levels does not appear to have been reported before. In previous studies the levels have been either unchanged (Cleve, 1968) or reduced (Snyder and Ashwell, 1971). Our study, however, is confined to one type of cancer at an early stage and is not strictly comparable with the previous studies quoted.

\section{Alsabti and Muneir}

There appear to be differences in the serum protein levels between women with breast cancer and those with benign breast disease. These differences are seen preoperatively at the earliest time of clinical detection of a breast tumour and do not appear to be related to the age difference between the groups. Raised serum ceruloplasmin has been reported previously in patients with both cancer and chronic inflammatory diseases $(8,9)$, but an increase in $\beta_{2}$ glycoprotein does not appear to have been reported before. In previous studies the levels have been either unchanged (3) or reduced (8). This study, however, is confined to one type of cancer at an early stage and is not strictly comparable with the previous studies quoted.
Two further examples of Dr Alsabti's plagiarism were cited in an article in Nature in June. ${ }^{4}$ One was a "close copy" of a paper published in the European fournal of Cancer in 1979.5 The copy appeared in the fapanese fournal of Medical Science and Biology, also in $1979 .{ }^{6}$ These two articles seem to have been submitted at roughly the same time, which suggests that $\mathrm{Dr}$ Alsabti must have got hold of a prepublication copy. Nature suggests that this happened because a copy for refereeing was sent by the European Fournal of Cancer to Dr J A Gottlieb, who had worked in the Anderson Centre in Houston, where Dr

Alsabti was at the end of 1978. Dr Gottlieb had died, however, and the paper sent to him was not recovered. The second example in Nature was an article "which seemed a copy of" an article published in the fapanese fournal of Clinical Oncology in 1977. ${ }^{7}$ It appeared in Oncology in $1979 .{ }^{8}$

Nature made an attempt to contact Dr Alsabti but failed. The address given in one of Alsabti's papers was the Royal Scientific Society, Amman, Jordan. But the Scientific Attache at the Jordanian Embassy said that, although he had heard of Dr Alsabti, he did not know his current whereabouts. The address on another paper was one in Brighton, but when a caller visited there nobody had heard of Dr Alsabti.

We can now add two further cases to this list, one of them concerning an article in a specialist journal published by the BMA. Dr K W Pettingale of King's College Hospital, has written to tell us of two of his papers that have been plagiarised by $\mathrm{Dr}$ Alsabti. One is a paper on serum proteins in breast cancer. Pettingale and Tee's paper was published in the fournal of

\section{Pettingale, Merrett, and Tee}

One hundred and sixty women admitted to King's College Hospital for breast tumour biopsy have been studied. Sixty-nine of these women were found to have breast cancer and 91 nonmalignant breast disease.

All the women were less than 70 years of age and had breast lumps less than $5 \mathrm{~cm}$ in diameter, with or without palpable ipsilateral axillary glands. Those with breast cancer therefore had tumours which fell into Clinical Stage I or II of the Manchester classification (Wise, Mason and Ackerman, 1971) and had no evidence of clinically occult metastases as shown by routine chest $x$-ray, liver function tests and serum chemistry, or bone scanning.

However, the measurement of serum immunoglobulin levels in breast cancer patients may be of some value as an indicator of tumour spread. There is a positive correlation between serum IgA level and the advancement of metastatic breast cancer, as quantified by the clinical score.

\section{Alsabti}

Eighty-one women admitted to the Main Royal Hospital for breast tumor biopsy have been studied. Thirtyone of these women were found to have malignant breast disease and 50 nonmalignant breast disease. Their ages ranged between 49-68 years. All had breast lumps less than five $\mathrm{cm}$ in diameter, with or without palpable axillary lymph nodes. Therefore those with breast cancer had tumors which fell into clinical stage I or II of the Manchester classification (Wise et al, 1971), and had no evidence of metastasis clinically as shown by chest $x$-ray, normal liver function tests, normal bone scanning and normal serum chemistry.

$$
\text { ... }
$$

The measurement of serum immunoglobulin levels in breast cancer patients is of value as an indicator of the disease spread. There is positive correlation between IgA level and the advancement of metastatic breast cancer, as quantified by the clinical score. 
Clinical Pathology in $1977^{\circ}$ and Alsabti and Muneir's in the fapanese Fournal of Experimental Medicine in 1979.10 Extracts from the discussions of the two articles are shown in the first box. The example is representative of the whole paper: some figures but few words have been changed.

In our second example (original paper by Pettingale, Merrett, and Tee in the British fournal of Cancer in 1977 ${ }^{11}$; plagiarised version by Alsabti in the fournal of Surgical Oncology in 197912) the figures and the text have been changed and some of the conclusions differ, but they are clearly essentially the same paper, as is shown by the extracts in the second box from the methods and the discussion.

When he wrote to the Lancet Professor Wheelock suggested that: "Editors of journals, on receiving review articles from individuals who have never published original research papers on the subject of the review, should verify the credentials of an individual." This should be possible; indeed, few if any of the well-established journals would consider publishing a review by somebody of whom they had never heard. But with original papers it is much more difficult. There are at least 8000 medical journals in the world, and many of these must receive thousands of papers a year (the $B M \mathcal{F}$ receives over 5000). Checking credentials of authors would be a vast and embarassing business. And checking to see if a paper has been published before (under a different name and probably with a different title) would be nigh on impossible. Though editors would seem to have little choice but to trust to the integrity of their contributors and the astuteness of their referees, perhaps the "Vancouver group" (the International Committee of Medical Journal Editors) might consider what action could be taken.

\section{References}

${ }^{1}$ Wheelock EF. Plagiarism and freedom of information laws. Lancet 1980 ; : 826.

2 Alsabti EAK. Tumour dormancy: a review. Cancer Res Clin Oncol 1979; $95: 209-20$.

${ }^{3}$ Alsabti EAK. Tumour dormancy: a review. Neoplasma 1979;26:351-61.

4 Anonymous. An outbreak of piracy in the literature. Nature 1980; 285:429-30.

5 Wierda D, Pazdernick TL. Suppression of spleen lymphocyte mitogenesis in mice injected with platinum compounds. Eur $\mathcal{f}$ Cancer 1979;15: 1013-23.

${ }^{6}$ Alsabti EAK, Ghalib ON, Salem MH. Effect of platinum compounds on murine lymphocyte mitogenesis. Fpn f Med Sci Biol 1979;32:53-65.

2 Yoshida T, Okazaki N, Yoshino M, Araki E. Diagnostic evaluation of serum lipids in patients with hepatocellular carcinoma. Fpn $\mathcal{f}$ Clin Oncol $1977 ; 7: 15-20$.

${ }^{8}$ Alsabti EAK. Serum lipids in hepatoma. Oncology 1979 ;36:11-4.

9 Pettingale KW, Tee DEH. Serum protein changes in breast cancer: a prospective study. $\mathcal{F}$ Clin Pathol 1977;30:1048-52.

${ }^{10}$ Alsabti EA, Muneir K. Serum proteins in breast cancer. $\mathcal{F p n ~}^{\mathcal{F}} \operatorname{Exp} \mathrm{Med}$ $1979 ; 49: 235-40$.

${ }^{11}$ Pettingale KW, Merrett TG, Tee DEH. Prognostic value of serum levels of immunoglobulins (IgG, IgA, IgM and IgE) in breast cancer: a preliminary study. Br $\mathcal{F}$ Cancer $1977 ; 36: 550-7$.

12 Alsabti E. Serum immunoglobulins in breast cancer. $\mathcal{F}$ Surg Oncol 1979; $11: 129-33$.

\section{MATERIA NON MEDICA}

\section{Walter Pater}

Some impulse made me think of Walter Pater and I asked the library for Richard Aldington's Walter Pater: Selected Works (1948). The book had to be brought from stock and I saw from the flyleaf that I was only the third person to take it out in the last four years. I bought my own copy of Marius the Epicurean in 1925 in New York, of all places, when I was living in a bachelor club on 52nd Street. When I was in the sixth form at school, just about the beginning of the 1914 war, we sedulously aped stylists such as Pater and the Robert Louis Stevenson of Virginibus Puerisque, and we imagined ourselves burning with the same "hard, gem-like flame." Fine writing of this kind was criticised by Somerset Maugham, who regarded writing purely as an instrument of communication, but I know I am not alone in finding writing a pleasure for writing's sake. Aldington's Selected Works is a rather forbidding, dark-bound, demy octavo book of 557 pages and it was some time before I felt strong enough to open it, but when I did, the previous charm at once exerted itself. Naturally I looked first at some of my old favourites, such as the description of Leonardo da Vinci's painting, "La Gioconda" (Mona Lisa). This is one of the most famous purple passages in English literature. It was a little too much for some of Pater's contemporaries, such as the Mark Pattisons, and it is still caviare, though all the more to be relished on that account. The "Mona Lisa" is indeed a remarkable picture, as E H Gombrich explains in his The Story of Art (1978), and Pater's "all the thoughts and experience of the world had etched and moulded there" is not greatly exaggerated. My surprise was to read for the first time Pater's The Child in the House (1878) and see how closely it resembles Proust's Du Côté de Chez Swann, published in 1913. Marius, said Aldington, "is most effective when read in brief portions of two or three chapters at a time." For me the same is true of $A$ la Recherche du Temps Perdu. In both authors the web of thought is so complex. Pater and Proust must both be of interest to medical men because of the degree to which they developed introspection and the detailed analysis of sensations. The Child in the House is a brilliant study of the way in which personality and identity are formed from sensory impressions received in early life. Like Proust, Pater was a solitary, but his position as a fellow and tutor at Brasenose College, Oxford, kept him in touch with people in his middle years. He had been one of Jowett's protégés and Jowett never forgave him when be became an aesthete and an agnostic, blocking his recognition and advancement within the university. Pater was an Epicurean, regarding pleasure as the only absolute good in life, but insisting that pleasures should be selected with intelligence and self-control. His attitude to religion was complex, "hesitating between Antiquity and Christianity, a reluctance to give up either, and a hopeless attempt, often abandoned always reviving, to find a satisfactory formula in which both were harmonised." In many ways, in life story, separateness, and college life, Pater resembles E M Forster, who lived in King's College, Cambridge, in his later years, and one imagines both of them shrinking as they heard the tramp of the hearties on the college stair outside their door.- $-\mathrm{L}$ J WITTS (emeritus Nuffield professor of medicine, Oxford).

\section{The boat}

The boat lay derelict on the golden sand. The tumbling surf, spent of its energy, swirled around its barnacle-encrusted hull. Glistening reflections from the beach were deadened by the black filth of the wooden gunwales. The propeller, bereft of all its power, shimmered in stark contrast to the grimy idle inboard engine. Oily bilgewater covered the floor of the squat-roofed cabin. A bundle of neatly tied chopsticks lay on a single dirty shelf. Scattered rice grains and prawn shells gave evidence of recent habitation. A discarded comb lay on deck.

The boat was barely eight metres long and so narrow it looked unstable. She had been beached the previous night, incongruously opposite the only tourist hotel in Songkhla, Southern Thailand. Fiftyfour refugees had made the perilous voyage from Vietnam. It seemed incomprehensible that so many could have survived such a long journey in such crowded insanitary conditions. There was so little room, with barely enough space to lie down and definitely no privacy possible. No smart set of sails graced this boat, only a dilapidated diesel engine of doubtful dependence. Where had their fuel been stored, and their food and water ? How had they passed the time? How long had the journey taken? Nobody knew. Only the boat remained as a stark reminder to human misery and suffering, for the refugees had all been taken away. The bystander was left to ponder the appalling risks that had been taken. Yet for them the risks had been worth while, even though this was just the start of the interminable refugee camps, interviews, selections, and uncertainty about tomorrow. But at least now there was hope. How many others lost that hope through capsize, starvation, disease, or from a direct attack by the many pirates who rove the area we will never know.-DONALD G DAwSON (occupational physician, Singapore). 